\title{
Conserving the endemic birds on the Comoro Islands, I: general considerations on survival prospects
}

\author{
MICHEL LOUETTE and JAN STEVENS
}

\section{Summary}

The status of the Comoro endemic birds is briefly reviewed. Field data were gathered during expeditions in 1981, 1983, 1985 and 1989.

Some native birds (Cyanolanius madagascarinus, Dicrurus fuscipennis on Ngazidja, Treron australis on Mwali, Accipiter francesae, Otus rutilus, Leptosomus discolor on Ndzuani, Dicrurus waldenii on Maore) are so rare that they are certainly highly endangered. The altitudinal stenotopy of a few other species makes them also very vulnerable, e.g. Zosterops mouroniensis in the tree-heath zone on Mount Karthala above 1,750 m. A preliminary analysis of habitat preference on Ngazidja suggests a relatively large flexibility of most forest species between different types of forest, including those with altered vegetation structure, but demonstrated their absence in plantations without large trees and/or natural shrubs. Comparison of density of species in Ngazidja and Mwali and an overview of the avifaunal composition on all four islands are the basis for a discussion on colonization history (with possible extinctions), historical change in avifaunal composition, the suitability of each island for the different species and the completeness of their avifauna. The results are checked for possible threats and necessary actions for conservation. Competition by introduced species does not yet seem to be a problem. But importation of foreign animals must be banned and hunting must be regulated (especially for pigeons). Habitat loss (overexploitation of the forest) will soon become a serious problem for the stenotopic forest birds. A suggestion is made for delimiting a national park on Ngazidja and Mwali. Most controversial is the development of tourism. For long-lasting results, education of local people is necessary, together with full liaison with the authorities.

Il s'agit d'un rapide réexamen du statut des oiseaux endémiques des îles Comores. Des données ont été rassemblées sur le terrain au cours d'expéditions effectuées en 1981, 1983, 1985 et 1989. Certains oiseaux de la région (Cyanolanius madagascarinus, Dicrurus fuscipennis sur l'île Ngazidja, Treron australis sur l'île Mwali, Accipiter francesae, Otus rutilus, Leptosomus discolor sur l'île Ndzuani, Dicrurus waldenii sur l'île Maore) sont tellement rares qu'ils sont certainement hautement menacés. La sténotopie d'altitude de quelques autres espèces les rend également très vulnérables, par exemple Zosterops mouroniensis dans la zone couverte de bruyère sur la montagne Karthala, au-dessus de 1,750 mètres. Une étude préliminaire des préférences d'habitat sur l'île Ngazidja suggère, pour la plupart des espèces forestières, une flexibilité relativement grande quant à leur choix entre les différents types de forêt, y compris ayant une structure végétale modifiée. En revanche, cette étude montre l'absence de toute espèce dans les plantations ne comportant pas de grands arbres et/ou arbustes naturels. La comparaison des densités d'espèces sur les îles Ngazidja et Mwali, ainsi qu'un examen de la composition avifaunique des quatres îles, 
sont la base d'une discussion sur l'histoire de la colonisation (avec les extinctions possibles), les changements historiques dans la composition avifaunique, l'adéquation de chaque île pour les différentes espèces et le caractère complet de leur avifaune. Les résultats sont vérifiés pour identifier les menaces possibles et les actions de conservation nécessaires. La compétition venant d'espèces introduites ne semble pas encore poser de problème. Mais l'importation d'animaux étrangers doit être prohibée et la chasse contrôlée (surtout pour les pigeons). La perte de l'habitat (sur-exploitation de la forêt) deviendra bientôt un problème sérieux pour les oiseaux forestiers sténotopiques. Une suggestion a efé faite pour démarquer un parc national sur les îles Ngazidja et Mwali. Le développement le plus controversé est celui du tourisme. Pour parvenir à des résultats à long terme, il est nécessaire d'éduquer la population locale, et d'établir une véritable liaison avec les autorités.

\section{Introduction}

The Comoro Islands in the Indian Ocean consist of a volcanically derived group of four main islands - three (Ngazidja, Mwali and Ndzuani) forming the Republic of the Comoros, the fourth (Maore) administered by France - to the north-west of Madagascar, and it is to the Malagasy faunal region or subregion that the islands belong.

Thirteen endemic bird species currently inhabit the Comoros. For a further 23 species endemic subspecies occur, some differing among the islands, representing a total number of 40 races (see Louette 1988a). The evolution of this native terrestrial avifauna presumably took place largely in a forested environment, although open spaces must have occurred regularly near lavaflows after volcanic activity. Man arrived some thousand years ago, causing a steady encroachment on and loss of the forest. This was most intensive in coastal areas, where this vegetation type has disappeared, whereas higher up the mountains it persists in varying quality, owing to natural factors and the different degrees of exploitation.

The present status of all native Comoro birds is examined here in relation to topographical and ecological factors (habitat and altitudinal preferences, density and possible competition from newly arrived generalists). A prediction of the chances for native bird survival in view of imminent extensive forest clearance and the birds' capacity to adapt to a modified environment is considered. The new environment consists largely of a chaotic agricultural landscape and a minor exotic afforested area.

\section{Study area and methods}

\section{The Comoro Islands}

The location of the islands and their position in the archipelago are indicated in Figures 1 and 2. Each of the four main islands - Ngazidja (Grand Comoro), Mwali (Moheli), Ndzuani (Anjouan) and Maore (Mayotte) - has its own particular avifauna, owing to colonization history (Louette 1988a, and in press). Ngazidja, by far the largest island, consists of two entities: La Grille (summit $1,087 \mathrm{~m}$ ) and Mount Karthala, which rises to 2,361 m; the avifauna of the former is an impoverished version of that of the latter. 


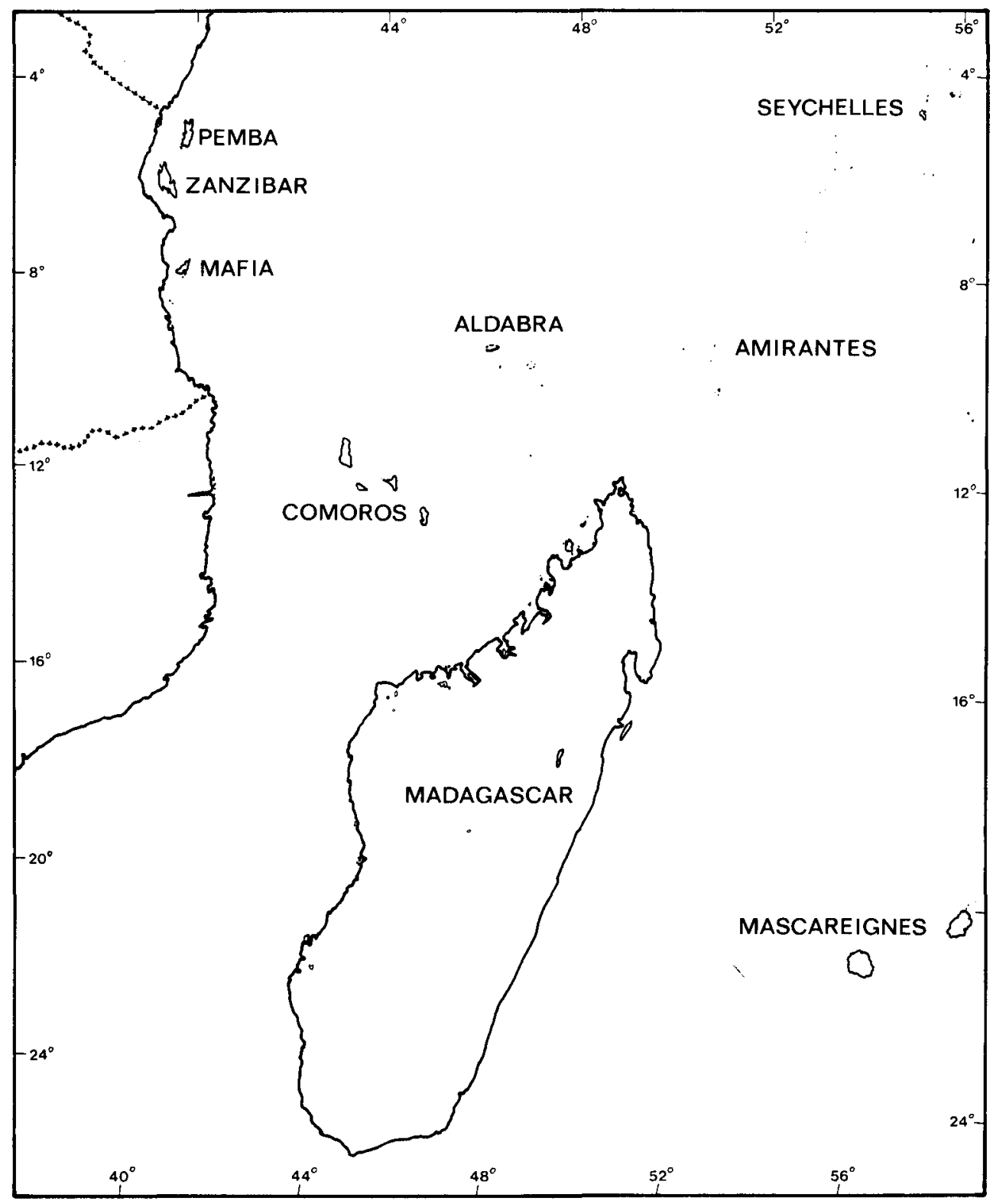

Figure 1. The Comoros in the western Indian Ocean.

The avifaunas give the general impression of being ecologically fairly "complete" (Diamond 1985, Louette et al. 1989; and see the island overviews below), but nothing is known about possible extinctions, which have been numerous on islands worldwide (Olson 1989); no fossils of importance have been studied on the Comoros. The avifauna contains a high proportion of non-passerines, including no less than six species of pigeon (this phenomenon is also found in the Bay of Bengal islands, another tropical semi-oceanic archipelago: Ripley and Beehler 1989). 


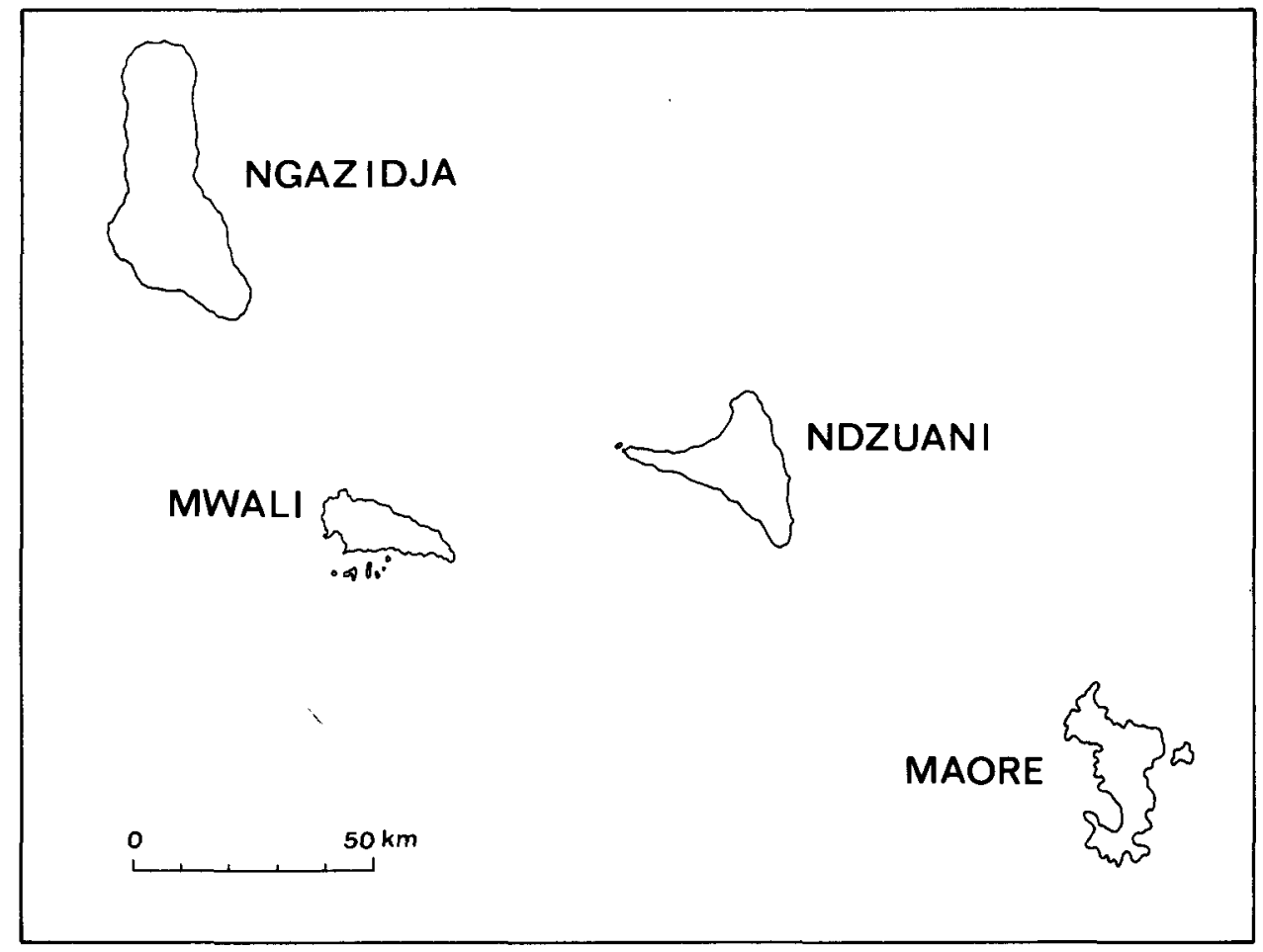

Figure 2. Position of the islands in the archipelago.

Because deforestation is complete in the coastal areas, the avifauna there is poorer in endemics and composed in part of recently arrived banal (non-forest) species. At higher altitudes, the forest (and tree-heath on top of Mount Karthala) is still present (although in low quantity and much fragmented on some islands, especially Ndzuani) and the typical avifauna persists at these levels, with only a minor addition of the banal species. In comparison with Benson's observations (1960), who was in the field in 1958, our data (1981-1989) show the forest has deteriorated, even within the latter period, although no significant decline of the native birds can be demonstrated.

\section{Counts of birds}

In 1981, 1983 and April 1985, through routine daily observations and mistnetting, preliminary information was gathered on the landbirds. Subsequent expeditions took place in September-October 1985 and November-December 1989, with the aim of collecting quantitative ecological and distributional data. This was done by point-counting on Ngazidja and Mwali (Bijnens et al. 1987, Louette et al. 1988). On the former, 15 stations spread out around Mount Karthala at all altitudinal levels from $0-2,000 \mathrm{~m}$ were used in 1985 , and 10 of them were used again in 1989, with six new ones added, including two at La Grille (Stevens and Louette 1990; see Figure 3). A station consists of 20 counts of 15 minutes each, by two persons (1o counts per person) at separate locations. On 


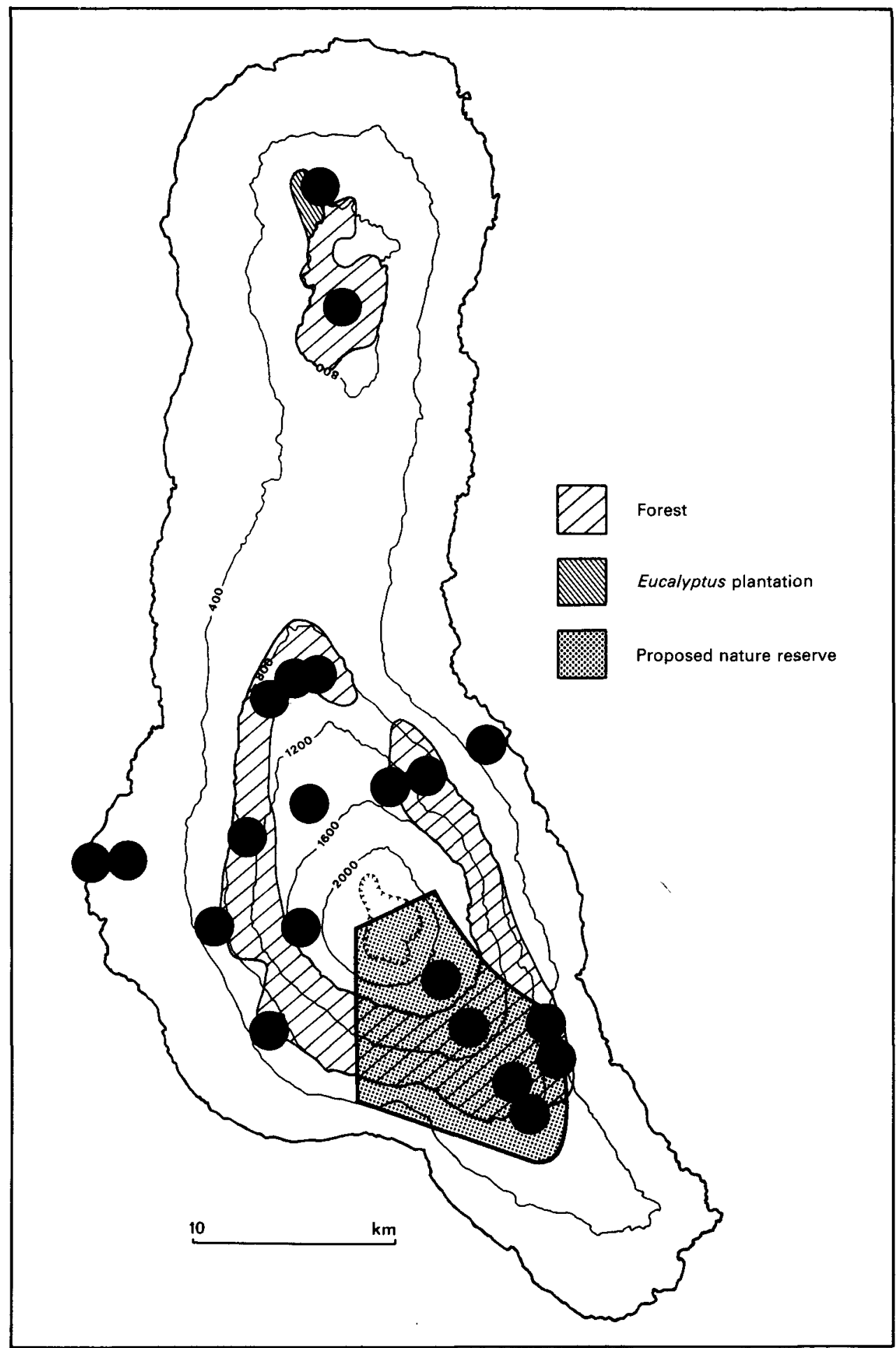

Figure 3. The distribution of forest on Ngazidja and one of the alternative perimeter propositions for a nature reserve (shaded); the other is the area above $1,400 \mathrm{~m}$. The dots represent point-count sites. 


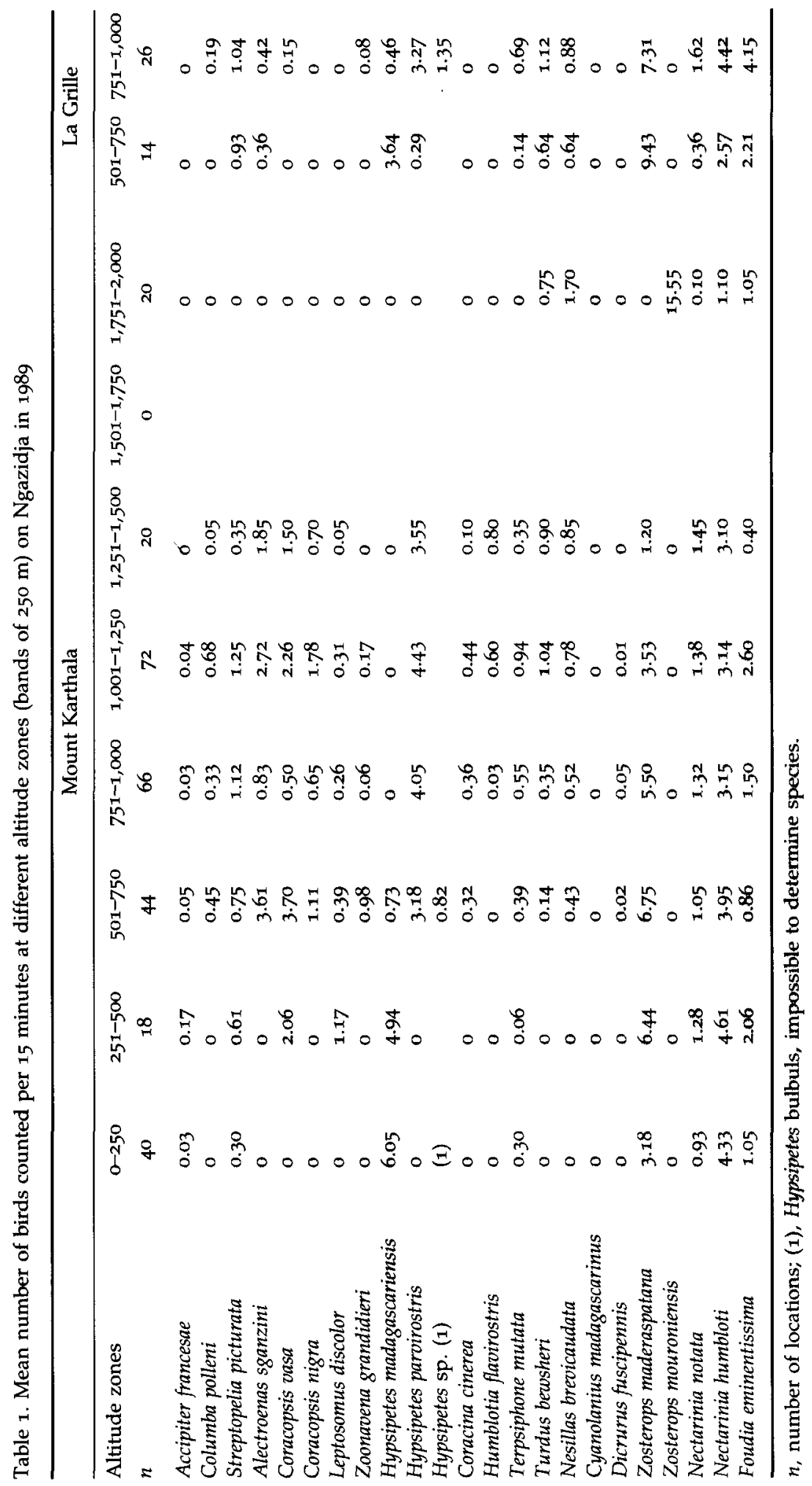


Mwali, in 1985, we counted at points evenly spread out along an altitudinal transect formed by a foot-path from sea level to virtually the top of the island at $700 \mathrm{~m}$, and repeated part of it in 1989. The following persons participated in the counts: L. Bijnens, M. Herremans, L. Janssens, M. Louette, J. Stevens and D. Vangeluwe. All were familiar with the birds on the islands, having studied either the birds in the field or illustrations and sound recordings intensively beforehand.

The numbers counted do not necessarily correspond to individuals, as double counting is unavoidable in some species; the numbers used here for altitudinal and habitat preference are useful for within-species comparisons. Relative density of forest species on Ngazidja and Mwali was calculated from our 1985 counts (Louette et al. 1989), not using numbers of birds counted but numbers of 15minute periods in which a species was observed, in order to compare relative density among species. The results of the comparison between years (1985 and 1989) and a bird diversity study are presented in Louette et al. (1990b).

\section{Results and discussion}

\section{Altitudinal distribution}

From the counts on Ngazidja, it is clear that the quality of the forest in itself is not the only factor to be correlated with a native bird's presence (Louette et al. 1988, 1989); altitude is also important. Using the data from 1985 (Louette et al. 1988) and those of 1989 (Table 1 ), the species on Mount Karthala can be divided into definite groups.

Species that occur on Mount Karthala over a wide altitudinal range are: Streptopelia picturata, Coracopsis vasa, Terpsiphone mutata, Zosterops maderaspatana, Nectarinia notata, N. humbloti and Foudia eminentissima. Clear preference for high altitudes is shown by Hypsipetes parvirostris, an altitudinal vicariant of $H$. madagascariensis (Louette and Herremans 1985). All these species are common to abundant; they also live on La Grille, with Coracopsis vasa in much lower, but Zosterops maderaspatana and Foudia eminentissima in rather higher abundance than on Mount Karthala. Leptosomus discolor and Dicrurus fuscipennis have a preference for low altitudes on Mount Karthala, being uncommon and very rare respectively. Also the uncommon Accipiter francesae belongs in this category in the counts, although at other times it was seen higher up. All three are absent from La Grille.

The following species are restricted to real forest: rather common ones are Alectroenas sganzini, Coracopsis nigra and Turdus bewsheri; less common and without clear altitudinal preference is Columba polleni. Humblotia flavirostris and Nesillas brevicaudata (both quite common) have a clear preference for the higher altitudes, Zoonavena grandidieri and Coracina cinerea (less common species) for the lower ones. Cyanolanius madagascarinus is extremely rare (seen twice around $900 \mathrm{~m}$ in 1981: Louette and Herremans 1982) and totally absent from our counts. The nocturnal Otus pauliani was not counted; its distribution is still insufficiently known, but it is definitely absent from lowland areas (Louette et al. 1990a, Herremans et al. 1991). Of these exclusively forest species on Mount Karthala, those concentrating at lower altitudes are absent from La Grille. This is not due 


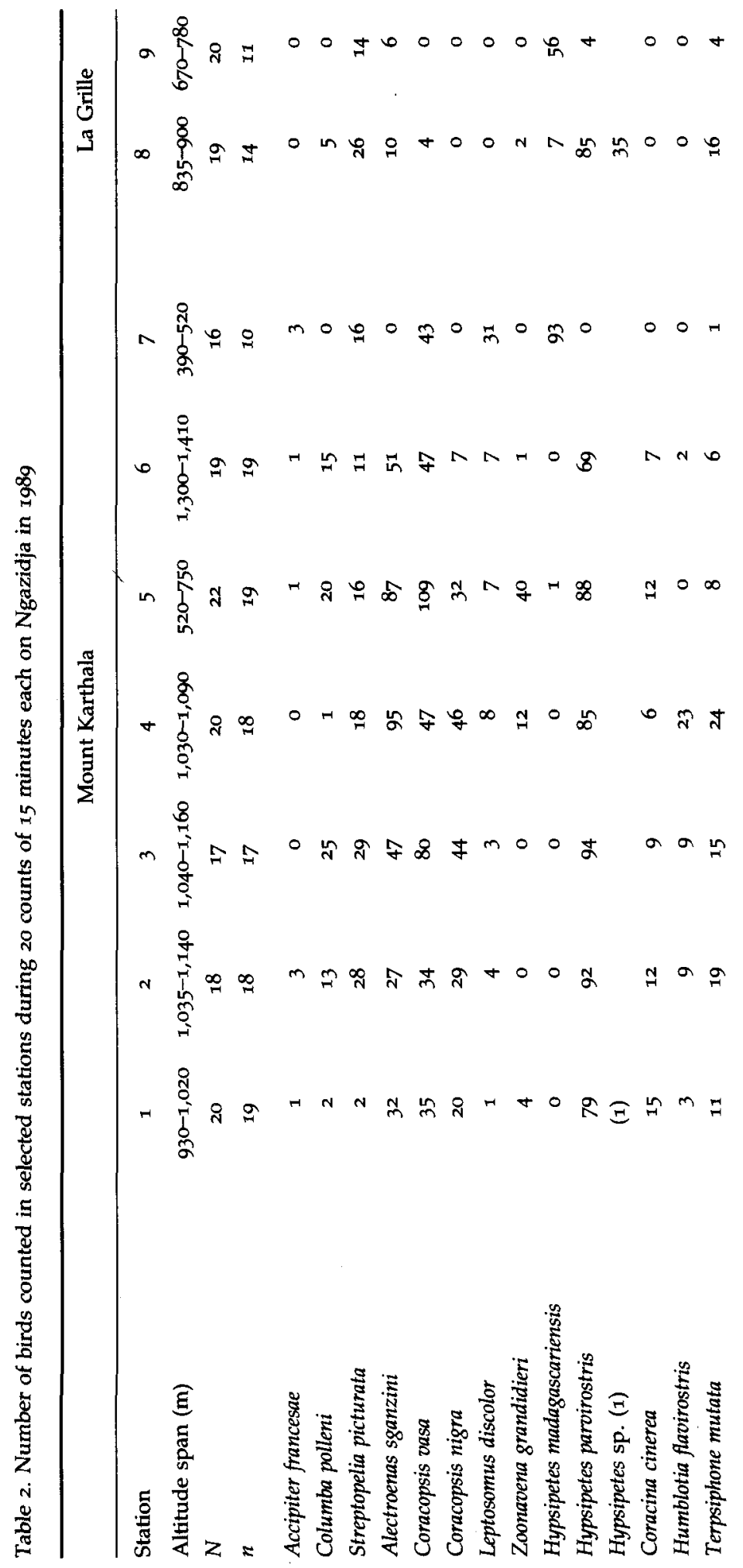




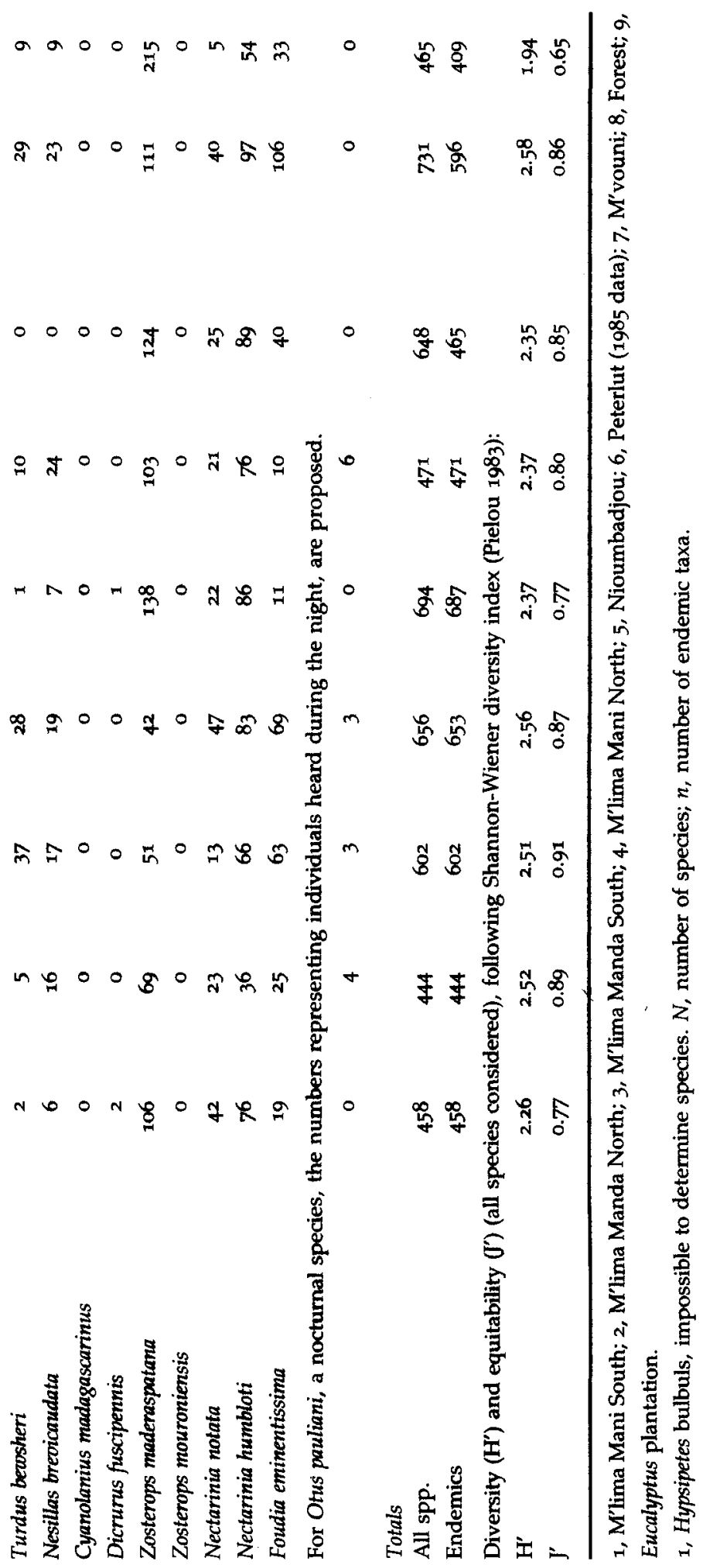


to the recent degradation of the forest there, since Benson (1960) did not find them in 1958 either. Also lacking at La Grille is the real montane bird Zosterops mouroniensis, living only on Mount Karthala above 1,750 m.

For the small island of Mwali, rising to $790 \mathrm{~m}$, there is no proof (the number of counts here is insufficient) of altitudinal preference in the forest. It is, nevertheless, anticipated for Columba polleni and Nesillas typica (see Louette et al. 1989) for the 1985 data; the 1989 data do not include the 250-500 m elevation zone); but the total altitudinal span is small and "high altitude" is invariably correlated with "better forest". The two other islands are intermediate in size, with Ndzuani rising to $1,595 \mathrm{~m}$, but because the forest has almost disappeared it is impossible to test the altitude factor there. On Maore, even less elevated than Mwali, with a peak of $660 \mathrm{~m}$, there is no purpose in testing this parameter, but the presence of much mangrove, virtually absent on Ngazidja, may produce quite different altitudinal preferences for some "forest" birds.

\section{Habitat preference on Ngazidja}

From our 1989 counts, we selected stations thought to be representative of the various forest types, but with a preponderance of data from the lower forest edge, the one most influenced by human activities. Table 2 gives the number of birds recorded in 20 counts of 15 minutes in each station.

In all forest types on Mount Karthala, the number of endemics is relatively high. In the young pioneer forests on lava flows (M'lima Mani South, and M'lima Manda North), the species lacking are those that are also absent in old primary forest (Cyanolanius madagascarinus) or that do not occur at that altitude elsewhere anyway, because of altitudinal restriction (Hypsipetes madagascariensis, Zosterops mouroniensis). Some species are present in lower numbers than in the older forests (Streptopelia picturata, Humblotia flavirostris and Turdus bewsheri). The last species needs a humid litter, absent in this environment. More numerous in this habitat than elsewhere are Coracina cinerea (preferring a well developed shrub layer), and Zosterops maderaspatana. This type of forest, which is not used for agricultural purposes, may also be important for the preservation of such a species as Otus pauliani.

In the old primary forests with altered vegetation structure due to cultivation (especially bananas and tarros), at M'lima Manda South and M'lima Mani North, we found native birds in great numbers. Foudia eminentissima was abundant in this habitat, foraging intensively on the flowers of banana trees. Diversity and relative abundance was high in these forests. Some species occurring here were absent from gardens and plantations: Alectroenas sganzini, Columba polleni, Coracopsis nigra, Zoonavena grandidieri, Coracina cinerea, Humblotia flavirostris, Turdus bewsheri and Nesillas brevicaudata. Accipiter francesae seems to adapt well to plantations. The number of endemics dropped drastically when the forest was further changed into a mosaic of plantations and gardens (such as at M'vouni), although Leptosomus discolor was numerous there.

At Nioumbadjou, a sawmill was active for decades until 1987 and the forest is degraded there due to the absence of large trees, although the shrub layer is regenerating. Some native forest birds were very numerous (Coracopsis vasa, Zoonavena grandidieri and Zosterops maderaspatana), but others were scarce (Terp- 
siphone mutata, Foudia eminentissima and possibly also Turdus bewsheri and Nesillas brevicaudata). The low relative abundance perhaps reflects a disturbed avifaunal community. The difference in bird abundances between 1985 and 1989 here (Stevens et al., next paper in this issue), seems to indicate that after a few years regenerating forest again becomes suitable for some species, but less so for others.

On La Grille, the forest is badly degraded, owing to cultivation of bananas and tarros. Surprisingly, the number of species is rather high and comparable to the Karthala stations, but the number of endemics is lower. Diversity and relative abundance are high because of the high number of (non-endemic) species. In a planted forest (mainly of Eucalyptus) at La Grille, we found a greater abundance of species, but fewer were native. Diversity and relative abundance are much lower here, with only Zosterops maderaspatana very numerous.

\section{Density}

Louette et al. (1989) found that, although there are fewer species present on Mwali than on Ngazidja (17 versus 21), the relative densities of all species are nearly the same. This phenomenon is known as density compensation for an "island" versus a "continent", and has been studied by Blondel (1985) for Corsica relative to southern France. Blondel predicted that (1) forest species would occur outside the forest on the island; (2) the largest species would be lacking on the island; and (3) those species that are less dense on the continent would be absent from the island. However, this does not hold true completely in this case. Concerning prediction (1), on Mwali Leptosomus discolor and Terpsiphone mutata do live more readily outside the forest, but these are different subspecies, with a different colonization history, making them more adaptable (Louette 1988a). Furthermore, Coracina cinerea and especially Foudia eminentissima seem to be more restricted to old forest on Mwali than on Ngazidja. Concerning (2), it is the large species in the genus Coracopsis that is present on Mwali (vasa), the small one (nigra) being absent. Concerning (3), while the rare Dicrurus fuscipennis is absent from Mwali, the equally rare Cyanolanius madagascarinus is present and commoner on Mwali. Thus, Mwali cannot be considered as a simple satellite of Ngazidja.

From our preliminary data it would appear that some species (Zosterops maderaspatana, Foudia eminentissima, Turdus bewsheri) also occur in higher abundance on impoverished La Grille than on Mount Karthala, possibly pointing also to density compensation in this case.

The extent to which density differences observed provide information on the prospects of survival for some of the species (due to lesser competition by other species) is still largely a matter of speculation.

\section{Avifaunal definition of each island}

\section{Maore}

Maore's geographical closeness to Madagascar is only reflected in bird relationships in a few cases (e.g. Terpsiphone mutata, with a closely related taxon); also, 
why are the two Malagasy genera Coracopsis and Nesillas lacking on this, the nearest island to Madagascar in the archipelago? These may have been extirpated locally, although they do survive on the three other islands, including the seemingly more degraded and only slightly larger Ndzuani. The absence of the small passerine Nesillas on Maore is unlikely to be due to extermination after habitat deterioration. Indeed, considering its size, Maore certainly has fewer species than the more pelagic western Comoros, but this may be due to its lesser elevation, certainly not to its distance from the source. Coracopsis and Nesillas are non-montane in Madagascar (see below) but in the western Comoros this is not so. These facts do not exclude Maore's possible historical function as a stepping stone in the colonization of the western Comoros from Madagascar. Its endemic Nectarinia coquereli is common and widespread in altitude and habitat. Its endemic Dicrurus waldenii lives at low density in particular forested sites.

\section{Ngazidja}

Of the five single-island endemics, only Nesillas brevicaudata is widespread, although only present at higher altitudes, above $500 \mathrm{~m}$. The four others (Otus pauliani, Humblotia flavirostris, Dicrurus fuscipennis, Zosterops mouroniensis) are limited to certain parts of Mount Karthala (Collar and Stuart 1985, Louette et al. 1988).

The species lacking on La Grille are both the truly montane (Zosterops mouroniensis, also Otus pauliani, Humblotia flavirostris) and the "crypto-lowland" forms. Crypto-lowlanders were scarce in our counts on the higher Karthala stations (Accipiter francesae, Coracopsis nigra, Leptosomus discolor, Coracina cinerea may also belong in this category), or generally scarce (Cyanolanius madagascarinus, Dicrurus fuscipennis). There is no lowland forest on the drier, smaller surroundings of the La Grille peak, and thus no chance for these species to establish a population in sufficient numbers there. On Mount Karthala, because this larger, wetter area still yields viable populations, they are possibly somewhat "pushed upwards" from their preferential lowland zone and can survive up to around $1,000 \mathrm{~m}$ at low density.

\section{Mwali}

Mwali's avifauna is quite similar to that on Ngazidja, which is about five times larger and much higher. They share endemics in the lineages Hypsipetes, Coracina, Nesillas, Nectarinia (twice), Cyanolanius and also Turdus (the Ndzuani representative is less close; Herremans 1988).

One of the striking insular characteristics, density compensation in comparison with its larger neighbour, seems to exist on Mwali (Louette et al. 1989 and see above). Two species live at higher density here than on Ngazidja: Turdus bewsheri and Cyanolanius madagascarinus, although none of these is present at sea level. All the species at low density on Ngazidja are lacking on Mwali. Species absent from Mwali, in comparison with Ngazidja, are also mostly absent from the La Grille part of that island. Ecologically these are mostly the larger insect(and vertebrate-) eating birds in the genera Accipiter, Otus, Zoonavena and Dicrurus, three of which are present in lowland Ndzuani. In a stable environ- 
Table 3. Female percentage of male bill length in Nectarinia

\begin{tabular}{llr}
\hline Taxon & \multicolumn{1}{c}{ Island } & $\%$ \\
\hline souimanga & Ndzuani & 87.5 \\
souimanga & Madagascar (1) & 92.8 \\
souimanga & Aldabra (2) & 93.5 \\
souimanga & Cosmoledo, Astove (2) & 93.5 \\
coquereli & Maore & 94.4 \\
humbloti & Ngazidja & 92.4 \\
humbloti & Mwali & 93.4 \\
notata & Ngazidja & 95.6 \\
notata & Mwali & 97.3 \\
notata & Madagascar & 92.8 \\
\hline
\end{tabular}

All data calculated from Benson (1960), except (1) from Benson et al. (1975), (2) from Benson and Penny (1971).

ment, insects are available in the same quantity year round, in contrast to fruit (Fogden 1972 for Sarawak). One would then predict that on a small island fruiteaters would have problems in surviving.

Mwali has been colonized directly at least twice from Madagascar (by Leptosomus discolor and Nesillas typica), yielding evidence that it is also in the zoogeographic sense not completely a satellite of Ngazidja. Also, as mentioned above, one would have expected Coracopsis nigra to occur instead of C. vasa. Mwali does have two species of Nectarinia in which the size difference in billlength between species is pushed to an extreme (largest of any in the large species, smallest of any in the smallest: Louette 1984). Its endemic species Nesillas mariae is not limited to the higher altitudes or virgin forest.

\section{Ndzuani}

Ndzuani derives some of its peculiar avifauna from Madagascar directly (Dicrurus forficatus, Nectarinia souimanga different at the subspecific level), not from the Ngazidja-Mwali group. However, its fauna does seem to be much impoverished in comparison with these two (although it is the only island in the group lacking endemic species). The forest is nearly gone and one wonders if some bird species were recently extirpated. An examination of the taxa present makes this unlikely for a number of genera: Ndzuani's only Nectarinia species has the most extreme sexual difference in bill-length in the genus for this general region (see Table 3), suggesting broad ecological coverage and making it unlikely that a larger congeneric species (e.g. notata on Madagascar, Ngazidja and Mwali) could ever have existed on the island. Its Nesillas (typica) is rather close to the second and most stenotopic forest species on Mwali, suggesting Ndzuani never harboured an offshoot of the other, Ngazidja-Mwali generalist species of Nesillas.

Although most of the native forest fauna has withdrawn to the upper levels, there is apparently still enough habitat available, suggesting no bird species has yet been lost due to habitat loss, especially since the larger species, more vulnerable to habitat degradation, are still present: Coracopsis (two species), Leptosomus discolor (rare), Columba polleni and Alectroenas sganzini. 
Ndzuani shares the non-Malagasy genus Turdus with the Ngazidja-Mwali cluster. Its Terpsiphone mutata and Foudia eminentissima (and perhaps Zosterops maderaspatana) populations are very close to the ones on Mwali, proving that it is not completely isolated zoogeographically from its neighbour, which is not unexpected, as it occupies a geographically central position in the archipelago.

\section{Ecology of birds in comparison with recruitment areas}

The status and both altitudinal and topographical distribution of most of the counterparts of the native Comoro birds on Madagascar, their principal source only a few are of continental African or possibly Asian descent (Louette in press) - can be found in Dee (1986). Because the prospects of survival for a species may be deduced from its ecology elsewhere, data of interest taken from that publication follow here in condensed form, and are compared with the different situation in the Comoros.

Circus maillardi is generally uncommon in Madagascar, although suitable habitat is abundant. This species is rather scarce on the large Ngazidja with apparently much suitable habitat (but perhaps generally too wet), whereas it is common on Mwali and Ndzuani, but almost completely absent from Maore (possibly due to hunting). Accipiter francesae is observed up to $1,800 \mathrm{~m}$, being a lowland but not a forest bird on Madagascar, nor is it on Ndzuani or Maore, but on Ngazidja it seems to prefer mesic habitat. Treron australis ranges up to $1,000 \mathrm{~m}$ in lowland Madagascar; on Mwali it is scarce and threatened by hunting, making a definition of its habitat impossible, but it was seen on top of the island's ridge. Cheke and Diamond (1986) suspected it was present in historical times also on Ngazidja and Ndzuani, possibly having been a lowland forest bird there. Coracopsis vasa ranges up to $1,000 \mathrm{~m}$. This species is semi-montane on the Comoros, even occurring at the top of La Grille, as others in this category (see above). Zoonavena grandidieri ranges up to $1,000 \mathrm{~m}$; it is "commoner at lower altitudes" on Madagascar, but a scarce mid-altitude bird on Ngazidja, the only island in the Comoros where it occurs, including La Grille. Cyanolanius madagascarinus ranges up to $1,500 \mathrm{~m}$ in Madagascar, "in treetops, mangroves". It is very rare on Ngazidja at mid-altitude and present on the higher levels of the non-montane Mwali. .

All other species of interest range widely but not exclusively in forest and are found at all altitudes in Madagascar, save for Agapornis cana, which is exclusively a lowland dweller there ( $0-1,000 \mathrm{~m}$ ), and Dicrurus forficatus, which prefers lowland $(0-1,000 \mathrm{~m})$ and is rare higher up.

Nectarinia notata, $N$. souimanga and Zosterops maderaspatana are specifically mentioned as entering Eucalyptus trees in Madagascar by Dee (1986).

Columba polleni, Turdus bewsheri and possibly Dicrurus fuscipennis are of nonMalagasy descent among Comoro native forest birds; their ecology is not known to differ from African members of these genera.

\section{Competition from introduced species}

The birds that successfully occupy the degraded areas at low and moderate altitudes of the Comoros were either introduced by man (Acridotheres tristis) or 
presumably only arrived after his activities started (Hypsipetes madagascariensis, Foudia madagascariensis, Lonchura cucullata). At present, there is no evidence of competition from introduced birds, although Acridotheres tristis nests in tree holes (as do native owls and parrots and Leptosomus discolor) in the lower and middle forest areas, and Foudia madagascariensis is locally sympatric with the endemic Foudia eminentissima (both species were observed to behave aggressively to each other on their territories). These fodies are known to hybridize on Madagascar.

Other introductions and recent arrivals are more locally successful but only in the lowlands (Streptopelia capicola, Turtur tympanistria, Agapornis cana) and are not taking over forest bird habitat.

In continental regions in general, newcomers most often invade regrowth areas (urbanized areas or artificial lakes, which would also be liable to invasion, are unimportant in the Comoros: Ulfstrand 1980). One introduced species which is expanding locally in the urban environment is Passer domesticus. Also passerines are mostly successful on continents, but here several non-passerines are invaders although such a species as Milvus migrans has been declining recently. This decline seems also to be the case for Corvus albus (Stevens and Louette 1990); possibly both cases are related to a change in livestock slaughtering practices by the human population.

One other banal species, Agapornis cana, according to our observations, seems to have been declining recently, although it has existed now for over 100 years in the Comoros (Benson 1960); elsewhere this bird apparently has a poor capacity for survival in exotic conditions (Baker 1990).

The only native species at all successful in degraded lowland habitats and exotic plantations are Zosterops maderaspatana - this is also the genus that does so in Mauritius - and Nectarinia humbloti.

Table 4. Overview of threatened endemic birds on the Comoros with reason for concern.

\begin{tabular}{|c|c|c|}
\hline & Habitat loss & Hunting \\
\hline Accipiter francesae & & Ndzuani \\
\hline Columba pollen $i^{\mathrm{a}}$ & & \\
\hline Treron australis & & Mwali \\
\hline Alectroenas sganzini $i^{\text {a }}$ & & All \\
\hline Coracopsis vasa & All (1) & \\
\hline Otus pauliani ${ }^{\mathrm{ab}}$ & Ngazidja & \\
\hline Otus rutilus & & Ndzuani \\
\hline Zoonavena grandidieri & Ngazidja & \\
\hline Leptosomus discolor & Ndzuani & \\
\hline Coracina cinerea & Mwali & \\
\hline Cyanolanius madagascarinus & Ngazidja (reason?) & \\
\hline Nesillas typica & Mwali & \\
\hline Humblotia flavirostris ${ }^{\mathrm{ab}}$ & Ngazidja & \\
\hline Zosterops mouroniensis ${ }^{\text {ab }}$ & Ngazidja & \\
\hline Foudia eminentissima & Mwali & \\
\hline Dicrurus fuscipennis $^{\text {ab }}$ & Ngazidja & \\
\hline Dicrurus waldenit ${ }^{\text {ab }}$ & Maore & \\
\hline
\end{tabular}

(1) does not occur on Maore. ${ }^{a}$ endemic species; ${ }^{b}$ species treated in Collar and Stuart 1985. 


\section{Recommendations}

\section{Prevention of habitat loss}

Cultivation extends to altitudes of 1,400 $\mathrm{m}$ in places on Mount Karthala; a road to the crater rim would condemn the forest and tree-heath at high altitude. Planning of land-use in general is a high priority in the Comoros and is understood by the local authorities and cooperative agencies alike.

The most urgent terrestrial problem is rainforest protection (Anon. 1987). A complete vegetation study, based on satellite images, should be carried out. This has been done for agricultural purposes already. It could be repeated for nature conservation uses. A field and a literature comparison could be carried out with the situation in such nearby islands as Mauritius and Réunion, where forest was cleared extensively about 30 years ago, with drastic consequences for the native birds (Cheke 1987). Because most native birds may not be immediately endangered on the Comoros, some time is available for study, especially to see if colonizing forest on recent lava-flows is a valuable compensation for the loss of mature primary forests. The study of forest bird density should be extended to the other islands to incorporate mangroves, possibly an alternative habitat for forest birds, especially on Maore. The country needs good legislation for land management and police intervention to have it enforced.

The problems for the forest are the collecting of firewood, the extraction of timber, and the clearance of the understorey and, locally, of big trees for the underplanting of vegetables and crops. Grazing by cattle is expanding and may in the long run become a major problem, prohibiting forest regeneration.

The birds very much threatened by habitat degradation are the endemic Ngazidja montane Zosterops mouroniensis (in tree heath) and Otus pauliani (in a particular type of forest) and the forest birds of $\mathrm{Ndzuani}$ in general. Threatened by habitat degradation (felling of forest) throughout the archipelago are some larger species such as Coracopsis vasa and Leptosomus discolor, needing nest-holes in big trees. Low-density birds that are locally threatened by habitat deterioration are: Dicrurus fuscipennis and Cyanolanius madagascarinus on Ngazidja (the endemic subspecies bensoni is the most threatened endemic race in the archipelago, not having been observed since its rediscovery in 1981), Nesillas typica on Mwali, Dicrurus waldenii on Maore.

It is still unclear where the limit of forest degradation lies for the endemic birds; we have the impression that the persistence of some large trees is essential for most of them. Habitat fragmentation (see Verner 1986) may also become a problem in the Comoros for the larger forest birds and possibly the cause of some absences at La Grille. It would be desirable to correlate bird occurrence with these factors and with the presence of native plants.

\section{Establishment of nature reserves}

A suggestion for a nature reserve on Mount Karthala has already been made elsewhere (Louette et al. 1988). The map in Figure 3 represents one of the possible alternatives. Endemic birds are the prime reason for this suggestion, because four single-island endemics of Ngazidja are limited to this mountain: 
Otus pauliani, Dicrurus fuscipennis, Humblotia flavirostris and Zosterops mouroniensis. The fifth Ngazidja single-island endemic Nesillas brevicaudata also occurs on the mountain, as do the multi-island endemic species Columba polleni, Alectroenas sganzini, Hypsipetes parvirostris, Turdus bewsheri and Nectarinia humbloti. All these species occur (and indeed have the core of their range) within the proposed perimeter drawn on Figure 3 but also, alternatively, above the 1,400 m contour.

With population pressure still low, Mwali is a prime candidate for the siting of a nature reserve, in part for its marine environment but also for its avifauna. Conversely, due to heavy human population pressure, there is little hope for establishing nature reserves on Ndzuani. For Maore, a paper describing the needs of the endemic avifauna was published separately (Louette 1988b) and a marine nature reserve is a high priority there.

A controversial area is tourism, still very undeveloped in the country. On the plus side is the cash income that would give an incentive for nature protection. On the minus side is the fear that any development in this sector would result in the creation of the long-announced but now temporarily abandoned Karthala road, which would no doubt bring many more people up the volcano, provoking the destruction of the sensitive plant community near the rim of Karthala's crater.

\section{Bird hunting regulations}

Pigeons in particular are hunted, on all islands (Louette 1988b); to a lesser degree all small birds are hunted with slingshots by some boys, but this is probably not affecting the native avifauna seriously. It is unknown if raptors suffer significantly.

Birds definitely threatened by hunting are: Treron australis on Mwali, possibly also Accipiter francesae and Otus rutilus on Ndzuani and Circus maillardi on Maore. Threatened by hunting in a general way are pigeons, especially Alectroenas sganzini (which is much prized for food) and no doubt also Columba polleni. Regulations should be established as a priority for these species.

\section{Ban on imported animals}

Introduced mammals are not yet known to be seriously harmful to the native terrestrial birds, but the introduced mongoose Herpestes auropunctatus is present on Ngazidja, this perhaps being the reason for the absence for breeding Puffinus on this island. Rats (at least Rattus rattus) and rasse Viverricula indica have been present for a long time on the four islands. A ban on further introductions of exotic species is required.

\section{Education in nature conservation}

The population of these islands being in large majority Moslem and the social life being very much related to religion, nature preservation could be much improved with the help of the Islamic religious authorities. Nature as a national heritage should be emphasized. The ecological and economic need for nature conservation should be explained. Agricultural and forest sustainability and 
climatological stability (e.g. for drinking water and fuelwood) all need to be promoted.

In 1989 we started a campaign which consisted of lessons at the teachers' college, a pamphlet, a poster, radio talks, newspaper articles, a permanent exhibit at the National Museum and the instruction of Ali Soilih, zoologist at the National Museum, in ornithological fieldwork and training, both locally and in Europe (Louette et al. 1990a).

\title{
Appendix. English names of species mentioned
}

\author{
Milvus migrans Black Kite \\ Circus maillardi Madagascar Harrier \\ Accipiter francesae Frances's Sparrowhawk \\ Columba polleni Comoro Pigeon \\ Streptopelia capicola Ring-nęcked Dove \\ Streptopelia picturata Madagascar Turtledove \\ Turtur tympanistria Tambourine Dove \\ Treron australis African Green Pigeon \\ Alectroenas sganzini Comoro Blue Pigeon \\ Coracopsis vasa Greater Vasa Parrot \\ Coracopsis nigra Lesser Vasa Parrot \\ Agapornis cana Grey-headed Lovebird \\ Otus pauliani Karthala Scops Owl \\ Otus rutilus Madagascar Scops Owl \\ Zoonavena grandidieri Madagascar Spine-tailed Swift \\ Leptosomus discolor Cuckoo-roller \\ Coracina cinerea Ashy Cuckoo-shrike \\ Hypsipetes madagascariensis Madagascar Bulbul \\ Hypsipetes parvirostris Comoro Bulbul \\ Cyanolanius madagascarinus Blue Vanga \\ Turdus bewsheri Comoro Thrush \\ Nesillas typica Madagascar Brush-warbler \\ Nesillas mariae Moheli Brush-warbler \\ Nesillas brevicaudata Grand Comoro Brush-warbler \\ Humblotia flavirostris Humblot's Flycatcher \\ Terpsiphone mutata Madagascar Paradise Flycatcher \\ Nectarinia souimanga Souimanga Sunbird \\ Nectarinia humbloti Humblot's Sunbird \\ Nectarinia coquereli Mayotte Sunbird \\ Nectarinia notata Long-billed Green Sunbird \\ Zosterops maderaspatana Madagascar White-eye \\ Zosterops mouroniensis Karthala White-eye \\ Lonchura cucullata Bronze Mannikin \\ Passer domesticus House Sparrow \\ Foudia madagascariensis Madagascar Fody \\ Foudia eminentissima Comoro Fody \\ Acridotheres tristis Common Myna \\ Dicrurus fuscipennis Grand Comoro Drongo \\ Dicrurus forficatus Crested Drongo \\ Dicrurus waldenit Mayotte Drongo \\ Corous albus Pied Crow
}




\section{References}

Anonymous (1989) République Fédérale Islamique des Comores. Etude de la stratégie agricole. Rapport principal. Ed. BDPA-SCETAGRI.

Baker, N. E. (1990) Three deletions from the avifauna of Tanzania. Scopus 14: 34-35.

Benson, C. W. (1960) The birds of the Comoro Islands: results of the British Ornithologists' Union Centenary Expedition 1958. Ibis 103b: 5-106.

Benson, C. W. and Penny, M. J. (1971) The land birds of Aldabra. Phil. Trans. R. Soc. Lond. B 260: 417-527.

Benson, C. W., Beamish, H. H., Jouanin, C., Salvan, J. and Watson, G. E. (1975) The birds of the Iles Glorieuses. Atoll Res. Bull. 176: 1-34.

Bijnens, L., Stevens, J., Janssens, L. and Louette, M. (1987) Community structure of Grand Comoro land birds with special reference to the ecology of congeneric species. Rev. Zool. Afr. 191: 221-232.

Blondel, J. (1985) Habitat selection in island versus mainland birds. Pp. 477-516 in M. L. Cody, ed. Habitat selection in birds. London: Academic Press.

Cheke, A. S. (1987) An ecological history of the Mascarene Islands, with particular reference to extinctions and introductions of land vertebrates. Pp. 5-89 in A. W. Diamond, ed. Studies in Mascarene Island birds. Cambridge, U.K.: Cambridge University Press.

Cheke, A. S. and Diamond, A. W. (1986) Birds on Moheli and Grand Comoro (Comoro Islands) in February 1975. Bull. Brit. Orn. Club 106: 138-148.

Collar, N. J. and Stuart, S. N. (1985) Threatened birds of Africa and related islands: the ICBP/ IUCN Red Data Book, part 1. Cambridge, U.K.: International Council for Bird Preservation.

Dee, T. J. (1986) The endemic birds of Madagascar. Cambridge, U.K.: International Council for Bird Preservation.

Diamond, A. W. (1985) The conservation of landbirds on islands in the Tropical Indian Ocean. Pp. 85-100 in P.J. Moors, ed. Conservation of island birds. Cambridge, U.K.: International Council for Bird Preservation (Techn. Publ. 3).

Fogden, M. P. L. (1972) The seasonality and population dynamics of equatorial forest birds in Sarawak. Ibis 114: 307-343.

Herremans, M. (1988) Inter-island variation in bird vocalizations on the Comoros. Proc. 6th Pan-Afr. Orn. Congr.: 281-295.

Herremans, M., Louette, M. and Stevens, J. (1991) Conservation status and vocal and morphological description of the Grand Comoro Scops Owls Otus pauliani Benson 1960. Bird Conserv. Internatn. 1: 123-133.

Louette, M. (1984) Le nombre d'espèces par genre (genus) aux Comores et aux îles avoisinantes. Africa-Terouren 30: 40-48.

Louette, M. (1988a) Les oiseaux des Comores. Ann. Mus. R. Afr. Centr. (Zool.) 255: 1-192.

Louette, M. (1988b) La conservation des oiseaux de Mayotte (Maore). Pp. 197-207 in J.-C. Thibault and I. Guyot, eds. Livre rouge des oiseaux menacés des départements, territoires et collectivités territoriales d'outre-mer. Paris: CIPO (Monogr. 5)

Louette, M. (in press) Origin and evolution of Comoro land birds. Proc. 7th Pan-Afr. Orn. Congr.

Louette, M. and Herremans, M. (1982) The Blue Vanga Cyanolanius madagascarinus on Grand Comoro. Bull. Brit. Orn. Club 102: 132-135.

Louette, M. and Herremans, M. (1985) Taxonomy and evolution in the bulbuls (Hypsipetes) on the Comoro Islands. Proc. Int. Symp. Afric. Vert. Bonn: 407-423.

Louette, M., Stevens, J., Bijnens, L. and Janssens, L. (1988) Survey of the endemic avifauna of the Comoro Islands. Cambridge, U.K.: International Council for Bird Preservation (Study Report 25). 
Louette, M., Herremans, M., Stevens, J. and Janssens, L. (1989) Comparison of forest bird communities on Ngazidja and Mwali (Comoro Islands). Ostrich (suppl.) 14: 33-37.

Louette, M., Stevens, J., Herremans, M. and Vangeluwe, D. (1990a) Red data bird: Grand Comoro Scops Owl. World Birdwatch 12 (1-2): 13.

Louette, M., Stevens, J., Herremans, M. and Vangeluwe, D. (1990b) Conservation training and avifaunal inventories on the Comoro Islands. Final report to ICBP. Unpublished.

Olson, S. L. (1989) Extinction on islands: man as a catastrophe. Pp. 50-53 in D. Western and M. Pearl, Conservation for the twenty-first century. Oxford: Oxford University Press.

Pielou, E. C. (1983) Populations and community ecology: principles and methods. London: Gordon and Breach.

Ripley, S. D. and Beehler, B. M. (1989) Ornithogeographic affinities of the Andaman and Nicobar Islands. J. Biogeogr. 16: 323-332.

Stevens, J. and Louette, M. (1990) Fluctuation of native forest bird abundances on Grand Comoro and prospects for conservation. Abstract XX Congr. Int. Orn.

Ulfstrand, S. (1980) Avifaunistic enrichment and bird community saturation. Acta XVII Congr. Int. Orn.: 1078-1081.

Verner, J. (1986) Predicting effects on habitat patchiness and fragmentation - the researcher's viewpoint. In: J. Verner, M. L. Morrison and C. J. Ralph, eds. Wildlife zooo: modeling habitat relationships of terrestrial vertebrates. Madison: University of Wisconsin Press.

\section{MICHEL LOUETTE}

Koninklijk Museum voor Midden-Afrika, B-308o Tervuren, Belgium

\section{JAN STEVENS}

Provinciaal Natuurcentrum, Zuivelmarkt 33, B-3500 Hasselt, Belgium 